\title{
Bronchorrhoea in a case of alveolar cell carcinoma
}

\author{
S. G. SPIRO, MARIE-TERESA LOPEZ-VIDRIERO, JANET CHARMAN1, I. DA $\overparen{\mathbb{Q}}$, \\ AND LYNNE REID
}

From the Department of Experimental Pathology, Cardiothoracic Institute, Brompton Hospital, London

SYNOPSIS In a case of bronchorrhoea associated with alveolar cell carcinoma the rheological and chemical features of the sputum indicated that it was bronchial fluid and not saliva and parot bronchial secretion, partly serum transudate. The viscosity and chemical constituents were similair to those found in bronchorrhoea when associated with chronic bronchitis, asthma, or bronchiectasis. The surfactant studies suggested an alveolar origin for most of the fluid, while the failure of flum restriction, corticosteroids, atropine, or cytotoxic drugs to influence the sputum volumeand propertie $\vec{\varepsilon}$ indicated that the cells responsible are 'autonomous'.

While the presenting features of alveolar cell carcinoma are as varied as those of other forms of pulmonary malignancy, a striking feature may be the production of large quantities of sputum, reported in single patients by Schools and Ray (1961), Kennamer (1951), and Wood (1943). In reviewing a series of 302 patients Storey, Knudtson, and Lawrence (1953), reported that 10 patients produced sputum in excess of $240 \mathrm{ml}$ per day, and two of these more than 3 litres.

Recently, interest has increased in the rheological properties and biochemical constituents of bronchial secretion in various diseases such as cystic fibrosis, chronic bronchitis, asthma, and bronchiectasis, but information on the composition of the sputum in bronchorrhoea due to alveolar cell carcinoma is only available from several cases (Warfringe, 1955; Biserte, Havez, Voisin, Delahousse, Cuvelier, and Gernez-Rieux, 1961; Bukantz and Berns, 1962; Gernez-Rieux, Biserte, Havez, Voisin, Cuvelier, and Roussel, 1963; Asselain, Uzzan, Roussel, and Degand, 1969; Voisin, 1969): proteins, bronchial glycoprotein, and electrolyte content were analysed.

The present report describes both the chemical composition and rheological features of the sputum from a patient with bronchorrhoea associated with alveolar cell carcinoma: all results are compared with those found in chronic bronchitis and in asthma and in bronchorrhoea associated with other diseases. The features typical of bronchorrhoea and the response to various methods of treatment are discussed.

1Janet Charman died suddenly after this paper had been accepted. Received for publication 9 October 1974.

\section{Case Report}

A 57-year-old male solicitor's clerk came to the Brompton Hospital in July 1973 with a five-week history of expiratory wheezing and cough productioge of a small amount of transparent, frothy sputurio. He felt perfectly well and had noticed no change in his effort tolerance. In 1957 he gave up smoking b. for 18 years before that had smoked about 20 cigarettes a day. He had never before noticed wheezing or any other feature suggesting chronic bronchitis or asthma and had had no serious illnes.

The only abnormal physical signs were coarise crepitations at the base of the left lung, and enlarge ment of the liver whose smooth edge was not tender but was palpable two fingerbreadths below the cost margin. The chest radiograph showed patchy co\& solidation of the left lower lobe, particularly of its apical segment. (A chest radiograph one year earlie. was normal.) His haemoglobin was $16.4 \mathrm{~g} / \mathrm{dl}$ and packed cell volume $0 \cdot 54$. The total white cell coun?, differential count, ESR, liver function tests, seruef urea, and electrolytes were normal. Complement fixation tests for common viruses and mycoplasn were negative. The forced expiratory volume 1 second $\left(F E V_{1}\right)$ was $2400 \mathrm{ml}$ (predicted normक्ष $3040 \mathrm{ml}$ ) and the vital capacity (VC) 3850 rif (predicted normal $4380 \mathrm{ml}$ ). Sputum culture was sterile for common pathogens and for $M$. tube $\vec{e}$ culosis. On seven occasions cytological examination of the sputum failed to reveal neoplastic cells. $\overrightarrow{A g}$ bronchoscopy, the mucosa appeared normal, the only abnormality being a large amount of watery fluid in the left lower lobe bronchus. No biopsy w 
taken, and in trap specimens of secretion no malignant cells were identified.

The patient was discharged on antibiotics and the radiographic appearance slightly improved, but within a week he was producing larger quantities of watery sputum, which he expectorated simply by bending forwards and without coughing. When he was readmitted early in November 1973 he had been producing about $700 \mathrm{ml}$ of sputum each day for six weeks, sputum which he complained tasted very salty. This troubled him most during the night since he was awakened several times by discomfort relieved by bringing up about a cupful of sputum. He still felt well, but now complained of some shortness of breath on walking at a fast pace. He had lost $2 \frac{1}{2} \mathrm{~kg}$ weight over the previous two months.

On examination the liver was larger but still smooth and not tender and other investigations showed little change, save that the total serum protein of $7 \cdot 3 \mathrm{~g} / \mathrm{dl}$ fell to $6 \cdot 1 \mathrm{~g} / \mathrm{dl}$ at the end of November, with normal albumin and globulin fractions. The $F E V_{1}$ and VC were both lower, being $1870 \mathrm{ml}$ and $2640 \mathrm{ml}$ respectively and the transfer factor (TLCO) was low, $3.8 \mathrm{mmol} \mathrm{min}^{-1} \mathrm{~K} \mathrm{~Pa}^{-1}$ (normal 8.7). The radiograph showed increased shadowing in the left lower lobe (see fig 1), and two weeks later some abnormal shadows were seen for the first time in the right lower lobe. Alveolar cell carcinoma was diagnosed from positive cytological findings on four of six sputum specimens.

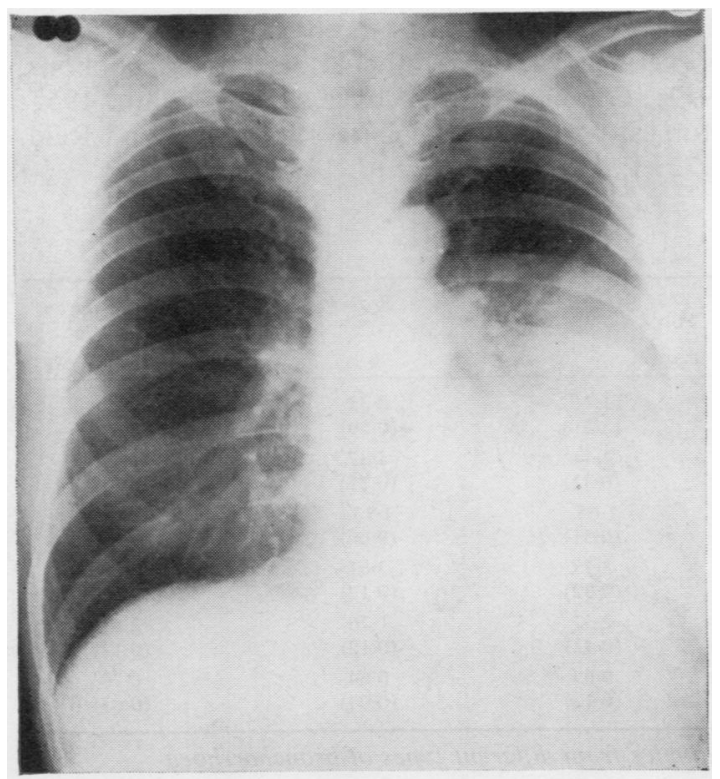

Fig 1 Chest radiograph in November 1973.
For three weeks all sputum was collected and detailed volumetric, rheological, and chemical analyses were carried out.

Since the tumour was thought to be inoperable, treatment, that unfortunately failed, was directed to reducing sputum volume-fluid restriction, prednisone $40 \mathrm{mg}$ daily, subcutaneous atropine to tolerance levels, and cytotoxic chemotherapy with cyclophosphamide, 5-fluorouracil, vincristine, and procarbazine in combination. The patient was discharged on 6 December 1973 on $40 \mathrm{mg}$ of prednisone a day but his condition deteriorated rapidly and he died at home later that month. Permission for a postmortem examination was not granted.

\section{Sputum Studies}

All sputum produced was collected so that the daily volume could be measured, but only that sputum produced between 6 am and $6 \mathrm{pm}$ was used in rheological and chemical studies. During these 12 hours sputum was collected over three-hour periods. At the end of the three hours aliquots for osmolality (Advanced Instruments Ltd osmometer model 3L) and viscosity studies (Ferranti-Shirley cone and plate viscometer over a shear rate of 0 to $1800 \mathrm{sec}^{-1}$ ) were taken and the tests made immediately. The remainder of the sputum was frozen at $-20^{\circ} \mathrm{C}$ and stored at the same temperature for chemical analysis. The following estimations were carried out: total macromolecular material (Warren, 1959), $\mathrm{N}$-acetyl neuraminic acid (NANA) (Warren, 1959), methylpentose-fucose (Gibbons, 1955), sulphate (Antonopoulos, 1962), mannose (Das, 1974). Total proteins (biuret method of Gornall, Bardawill, and David, 1949), albumin (Doumas, 1971), and calcium (AutoAnalyzer) estimations were carried out by the Biochemistry Department of the Brompton Hospital. Fresh sputum samples were centrifuged at $5000 \mathrm{~g}$ at $4^{\circ} \mathrm{C}$ for 1800 seconds (MSE automatic Superspeed 65 ultracentrifuge).

\section{Results}

In our patient the daily sputum volume and its macroscopic appearance were typical of bronchorrhoea-a watery, transparent fluid topped by copious froth. The sputum volume varied from $630 \mathrm{ml}$ to 1 litre, with a mean value of $843 \mathrm{ml}$, being more than in other cases of bronchorrhoea we have studied. Neither the rate of sputum production nor the viscosity and chemical constituents showed the circadian rhythm seen in other diseases (Charman, 1974; Lopez-Vidriero, 1974).

Mean levels for viscosity, dry weight $(\mathrm{mg} / \mathrm{ml})$, 


\begin{tabular}{|c|c|c|c|c|c|c|}
\hline & Serum & Saliva & $\begin{array}{l}\text { Chronic } \\
\text { Bronchitis } \\
\text { (mucoid) }\end{array}$ & Asthma & Bronchorrhoae & $\begin{array}{l}\text { Alveolar Cell } \\
\text { Carcinoma } \\
\text { (patient) }\end{array}$ \\
\hline Viscosity (poise) & 0.01 & 0.03 & 0.34 & 0.71 & $0 \cdot 24$ & $0 \cdot 10$ \\
\hline Osmolality (milliosm $/$ kg) & 285 & 53 & 304 & 159 & 157 & 294 \\
\hline Dry weight $(\mathrm{mg} / \mathrm{ml})$ & 80.44 & $2 \cdot 50$ & $18 \cdot 82$ & $22 \cdot 41$ & 10.01 & $5 \cdot 78$ \\
\hline NANA $(\mathrm{mmol} / \mathrm{l})$ & $2 \cdot 10$ & 0.06 & $2 \cdot 68$ & $2 \cdot 97$ & 1.68 & 0.42 \\
\hline Fucose $(\mathrm{mmol} / \mathrm{l})$ & $0 \cdot 36$ & $0 \cdot 24$ & 6.03 & $5 \cdot 84$ & $2 \cdot 37$ & 0.73 \\
\hline Sulphate (mmol/l) & 0.90 & $0 \cdot 10$ & $2 \cdot 20$ & $1 \cdot 70$ & $1 \cdot 10$ & $0 \cdot 30$ \\
\hline Mannose (mmol/l) & $13 \cdot 49$ & $0 \cdot 16$ & 0.77 & 0.99 & 0.83 & $0 \cdot 11$ \\
\hline NANA/fucose ratio & $5 \cdot 83$ & 0.26 & 0.44 & 0.51 & 0.71 & 0.77 \\
\hline
\end{tabular}

Table I Rheological and chemical results from serum, saliva, and sputum

${ }^{1}$ Associated with chronic bronchitis, asthma, bronchiectasis, or scleroderma

NANA, fucose, sulphate, and mannose concentration were found to be below the range of other bronchorrhoea sputum we have studied, significantly lower than mucoid chronic bronchitic sputum, but still higher than in saliva (except for mannose). The NANA/fucose ratio was within the range for bronchorrhoea and significantly higher than in mucoid bronchitic sputum or saliva (table I). The mannose content of the single sputum studied was $0.094 \mathrm{mmol} / \mathrm{l}$, well below serum levels and about 10 times lower than that found in other diseases (table I). Other chemical estimations included total proteins $(0.6 \mathrm{~g} / \mathrm{dl})$, albumin $(0.3 \mathrm{~g} / \mathrm{dl})$ and calcium $(1.7 \mathrm{mmol} / \mathrm{dl})$. Total proteins and albumin levels were within the chronic bronchitic range (Brogan, Ryley, Allen, and Hutt, 1971; Ryley and Brogan, 1973) but calcium was found to be higher than in chronic bronchitic sputum (Brogan et al, 1971).

Thus the most characteristic feature of sputum from any bronchorrhoea patient, when compared with sputum from other diseases such as chronic bronchitis, asthma, bronchiectasis, and cystic fibrosis, is still the sputum volume since some of the chronic bronchitic mucoid sputum samples showe viscosity and chemical values within the range fog bronchorrhoea.

When comparing the results in the patiens described here with other cases of bronchorrhoe associated either with chronic bronchitis, asthmo bronchiectasis, or scleroderma (Charman, LopezVidriero, Keal, Mitchell-Heggs, and Reid, 1974) significantly lower levels were found in our patien? for dry weight $(\mathrm{mg} / \mathrm{ml})$ NANA and fucose (as percentage and $\mathrm{mmol} / \mathrm{l})$. No significant differencs was found for the NANA/fucose ratio (table II).

Viscosity showed a significant correlation wit dry weight $(\mathrm{P}>0.001)$ and fucose $\left(\mathrm{mmol} / \mathrm{l} \mathrm{P}>\frac{\mathrm{D}}{\mathrm{Q}}\right.$ 0.01 ) as has been reported for other diseases (Lopez Vidriero, Charman, Keal, de Silva, and Reid, 1973) a significant correlation was not found with NANA $(\mathrm{mmol} / \mathrm{l})$ although a positive correlation between the level and viscosity has been reported by man workers in various epithelial secretions (Gibbons? 1959; Gibbons and Glover, 1959; Odin, 1955\% Munies, Grubb, and Caliari, 1968; Keal and Reid. 1972; Lopez-Vidriero et al, 1973).

\begin{tabular}{|c|c|c|c|c|c|}
\hline Chemical Constituents & $\begin{array}{l}\text { Alveolar Cell } \\
\text { Carcinoma } \\
\text { (Present Case) }\end{array}$ & $\begin{array}{l}\text { Chronic } \\
\text { Bronchitis }\end{array}$ & Asthma & Bronchiectasis & Scleroderma \\
\hline Dry weight $(\mathrm{mg} / \mathrm{ml})$ & $\begin{array}{c}5.78 \\
(1.47)^{1}\end{array}$ & $\begin{array}{l}14 \cdot 5 \\
(5 \cdot 23)\end{array}$ & $\begin{array}{l}11 \cdot 41 \\
(3 \cdot 2)\end{array}$ & $\begin{array}{c}8 \cdot 35 \\
(0 \cdot 59)\end{array}$ & $\begin{array}{l}14 \cdot 11 \\
(1 \cdot 39)\end{array}$ \\
\hline NANA ( $\%$ dry weight) & $\begin{array}{c}2 \cdot 51 \\
(0 \cdot 21)\end{array}$ & $\begin{array}{c}3.47 \\
(0.86)\end{array}$ & $\begin{array}{c}4.44 \\
(0.42)\end{array}$ & $\begin{array}{c}4 \cdot 37 \\
(0 \cdot 12)\end{array}$ & $\begin{array}{r}4 \cdot 27 \\
(0 \cdot 4)\end{array}$ \\
\hline NANA (mmol/l) & $\begin{array}{c}0.42 \\
(0.06)\end{array}$ & $\begin{array}{c}1.42 \\
(0.38)\end{array}$ & $\begin{array}{l}1.65 \\
(0.51)\end{array}$ & $\begin{array}{l}1.13 \\
(0.06)\end{array}$ & $\begin{array}{c}1 \cdot 84 \\
(0 \cdot 16)\end{array}$ \\
\hline Fucose $(\%$ dry weight $)$ & $\begin{array}{c}2 \cdot 25 \\
(0 \cdot 27)\end{array}$ & $\begin{array}{c}4 \cdot 19 \\
(0 \cdot 41)\end{array}$ & $\begin{array}{c}3.77 \\
(0.32)\end{array}$ & $\begin{array}{c}3.61 \\
(0 \cdot 17)\end{array}$ & $\begin{array}{c}3 \cdot 26 \\
(0 \cdot 18)\end{array}$ \\
\hline Fucose (mmol/1) & $\begin{array}{c}0.73 \\
(0.06)\end{array}$ & $\begin{array}{l}3 \cdot 22 \\
(0 \cdot 79)\end{array}$ & $\begin{array}{c}2 \cdot 37 \\
(0 \cdot 42)\end{array}$ & $\begin{array}{c}1 \cdot 76 \\
(0 \cdot 12)\end{array}$ & $\begin{array}{c}2.61 \\
(0.12)\end{array}$ \\
\hline NANA/fucose ratio & $\begin{array}{c}0.77 \\
(0.17)\end{array}$ & $\begin{array}{c}0.44 \\
(0.12)\end{array}$ & $\begin{array}{c}0.69 \\
(0 \cdot 12)\end{array}$ & $\begin{array}{c}0.64 \\
(0.04)\end{array}$ & $\begin{array}{c}0.70 \\
(0.03)\end{array}$ \\
\hline
\end{tabular}

Table II Standard error for chemical constituents in sputum samples from different types of bronchorrhoea 


\begin{tabular}{|c|c|c|c|c|c|c|c|c|}
\hline \multirow[t]{2}{*}{ Material } & \multicolumn{2}{|c|}{ Dry Weight $(\mathrm{mg} / \mathrm{ml})$} & \multicolumn{2}{|c|}{ NANA (mmolll) } & \multicolumn{2}{|c|}{ Fucose (mmolll) } & \multicolumn{2}{|c|}{ NANA/Fucose Ratio } \\
\hline & Sample 1 & Sample 2 & Sample 1 & Sample 2 & Sample 1 & Sample 2 & Sample 1 & Sample 2 \\
\hline $\begin{array}{l}\text { Whole sputum } \\
\text { Sol phase } \\
\text { Gel phase }\end{array}$ & $\begin{array}{l}5 \cdot 23 \\
4 \cdot 72 \\
8 \cdot 75\end{array}$ & $\begin{array}{r}6.94 \\
4.29 \\
11.90\end{array}$ & $\begin{array}{l}0.29 \\
0.26 \\
0.32\end{array}$ & $\begin{array}{l}0.65 \\
0.32 \\
0.90\end{array}$ & $\begin{array}{l}0.30 \\
0.24 \\
0.91\end{array}$ & $\begin{array}{l}1 \cdot 70 \\
0.55 \\
2 \cdot 25\end{array}$ & $\begin{array}{l}0.96 \\
1.08 \\
0.35\end{array}$ & $\begin{array}{l}0.37 \\
0.58 \\
0.40\end{array}$ \\
\hline
\end{tabular}

Table III Centrifugation studies of the chemical constituents of two sputum samples from patient with bronchorrhoea and alveolar cell carcinoma

Two samples were centrifuged at $5000 \mathrm{~g}$ and the chemical estimations were carried out separately on the sol and gel phase. Compared with the sol phase the gel contained about twice as much solid macromolecular material and had a fucose concentration about three times as great (table III). The NANA content was low in whole sputum and in both of its phases, and in contrast to other types of bronchorrhoea and chronic bronchitis the NANA/fucose ratio was lower in the gel phase than in the sol (Lopez-Vidriero, 1974).

The osmolality of sputum was higher than is usual in bronchorrhoea or asthma and within the chronic bronchitis range (table I).

Samples of sputum with large amounts of froth were sent to Professor R. E. Pattle for surfactant studies. He reported that the froth was of a gelatinous nature consisting of typical alveolar bubbles lined with lung surfactant as shown by stability tests and treatment with antifoam.

In our patient continuous prednisone for six weeks and also subcutaneous atropine, fluid restriction, and a course of four cytotoxic agents made no impression on the daily sputum volume. There was no significant change in either the rheological properties or chemical constituents of the sputum. During fluid restriction neither sputum nor plasma osmolality changed, but that of urine increased (table IV). Thus the lung secretion seemed to be independent of the overall fluid balance and was not influenced by the homeostatic response to fluid restriction (fig 2).

\begin{tabular}{lll}
\hline Material & $\begin{array}{l}\text { Before Fluid } \\
\text { Restriction }\end{array}$ & $\begin{array}{l}\text { During Fluid } \\
\text { Restriction }\end{array}$ \\
\hline Sputum & 288 & 304 \\
Plasma & 300 & 292 \\
Urine & 477 & 993 \\
\hline
\end{tabular}

Table IV Sputum, plasma, and urine osmolality (milliosm $/ \mathrm{kg}$ ) before and during fluid restriction

\section{Discussion}

The patient presented here had bronchorrhoea by definition since his daily sputum production was in excess of $100 \mathrm{ml}$ (Keal, 1971a).

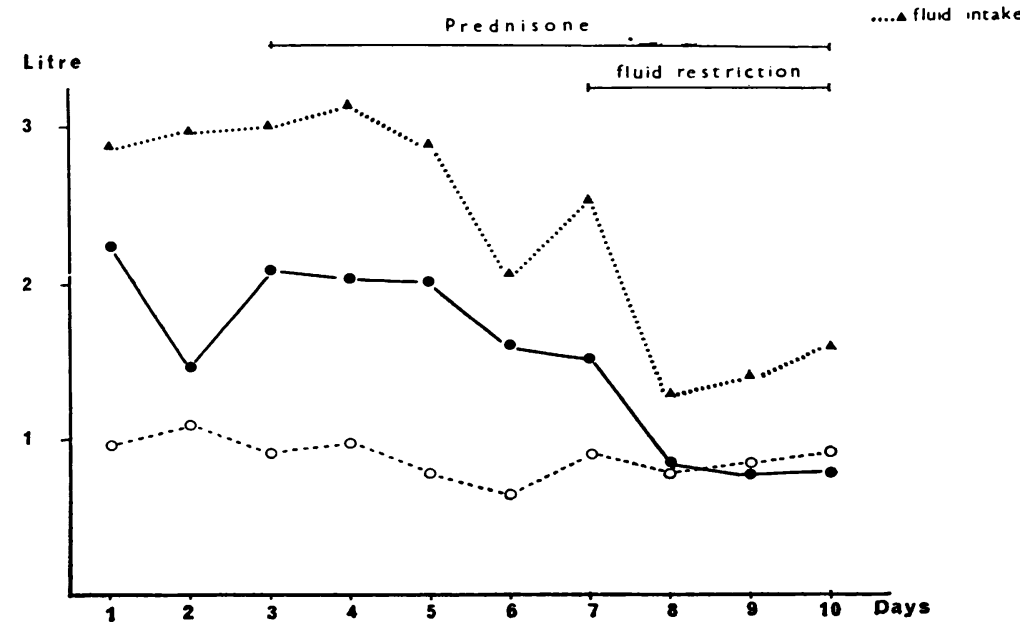

Fig 2 Sputum volume and urine output during fluid restriction. 
The chemical and rheological studies indicate that this patient's bronchial fluid was not saliva but partly bronchial secretion partly serum transudate. The viscosity was higher than that of either saliva or serum and fell within the range found in other types of bronchorrhoea and hence lower than expected for mucoid chronic bronchitic sputum. Since fucose comes from epithelial glycoprotein not from serum, the significant correlation between viscosity and fucose but not with NANA suggests that a secreted glycoprotein, perhaps a mainly neutral one, was responsible for the rheological properties of the patient's sputum.

It has been reported that the gel phase of chronic bronchitic sputum contains the bronchial glycoprotein, some serum proteins and glycoproteins bound to the bronchial glycoprotein (Biserte, Havez, and Cuvelier, 1963), while in the sol phase are found any soluble components of bronchial secretion and also serum proteins (Ryley and Brogan, 1973). In our patient, taking absolute values and the NANA/ fucose ratio in whole sputum and after centrifugation in sol and gel phases, the results suggest that our patient's sputum contained bronchial secretion but that the glycoprotein secreted was less acid than usual and mainly a neutral fucomucin, eg, a blood group substance. These findings agreed with other studies reported by Wartringe (1955), Gernez-Rieux, Voisin, Macquet, Clayes, Piat, and Fournier (1961), Asselain et al (1969), and Voisin (1969) in patients with alveolar cell carcinoma.

The surfactant studies seem to indicate an alveolar origin for most of the fluid since agitation of the liquid part of the sputum did not result in stable bubble formation, suggesting that epithelial glycoproteins arise from the tumour cells lining the alveoli and the failure to respond to treatment suggests that this may be autonomous.

The daily sputum production, viscosity levels, and NANA/fucose ratio fell within the range found in other cases of bronchorrhoea associated with chronic bronchitis, asthma, or bronchiectasis, while the dry weight, NANA, and fucose content were lower than in other types of bronchorrhoea. The osmolality was significantly higher, possibly due to a high ionic concentration, a chemical feature reported by Gernez-Rieux and his colleagues (1961) in a case of bronchorrhoea associated with alveolar cell carcinoma.

Treatment of bronchorrhoea associated with alveolar cell carcinoma or other pulmonary diseases may be directed either to reducing the bronchial secretion as by parasympathetic blocking drugs or corticosteroids or to decreasing the serum transudate as by antihistamine drugs or corticosteroids, depending on the cause of the excessive sputum.
There is no information on the effect of resection in alveolar cell carcinoma.

Organ culture studies have shown that in certait patients corticosteroids reduce the secretion of mucus by the bronchial glands, possibly due to membrane effect (Sturgess, 1972). Also corticoig steroids have been successful in treating some cases of bronchorrhoea associated with extrinsic of intrinsic asthma (Keal, 1971a), especially when the sputum level of NANA is low. A less dramatic response was observed with antihistamine drug and subcutaneous atropine in bronchorrhoea with extrinsic asthma (Keal, 1971b).

In only a few cases of bronchorrhoea associate@ withalveolar cell carcinoma has treatment of sputura volume been attempted and any success has beep temporary. In one case infiltration of the stellate ganglion was followed by reduction of the sputum volume from $300 \mathrm{ml}$ to $150 \mathrm{ml}$ for two week (Bourgeois, Delarue, Garaix, and Brien, 1950? Gernez-Rieux et al (1961) reported some decrease after subcutaneous injections of atropine and orat belladona. Siltzbach (personal communication found that ACTH produced a dramatic, but temporary, reduction in the sputum volume of fouw patients with bronchorrhoea associated with alveola cell carcinoma.

In other cases treated with atropine, corticő steroids, infiltration of the stellate ganglion, intra venous procaine, radiotherapy and antihistamin $\vec{E}$ no reduction in sputum was obtained (Bourgeo 3 et al, 1950; Rubinstein and Pilheu, 1954; Turiaf Marland, and Sors, 1957; Gernez-Rieux et al, 1961 In our patient, although the NANA level in sputuris was low, corticosteroids failed to reduce the volume

References

Antonopoulos, C. A. (1962). A modification for the determination $\mathscr{f}$ sulphate in mucopolisaccharides by the benzidine method. Acta chem. scand., 16, 1521-1522.

Asselain, R., Uzzan, D., Roussel, P., and Degand, P. (1969). Etuco clinique, anatomique et biochimique d'une observation de cancer bronchiolo-alvéolaire hypersécrétant. Colloque Inteo nationale Pathologie de Thoracique. (Lille 1968), pp. 101-114:

Biserte, G., Havez, R., and Cuvelier, R. (1963). Les glycoprotéidês des sécretions bronchiques. Exp. ann. Biochim. méd., 24, 85-12ब,

Biserte, G., Havez, R., Voisin, C., Delahousse, P., Cuvelier, R., arfe Gernez-Rieux, C. (1961). Etude de la composition protidique de l'expectoration dans les bronchorrhées chroniques. T. Apport des méthodes électro-immuno-électro-phorétiques. $\mathrm{Li}$ Méd., 6, 51-61.

Bourgeois, P., Delarue, J., Garaix, J. P., and Brien, C. (1950@् Bronchorrhée hydròmuqueuse incoercible à évolution malignè. J. franc. Méd. Chir. thor., 4, 584-589.

Brogan, T. D., Ryley, H. C., Allen, L., and Hutt, H. (1971). Relatioß between sputum sol phase composition and diagnosis chronic chest diseases. Thorax, 26, 418-423.

Bukantz, S. C., and Berns, A. W. (1962). Studies with sputum. IID Paper electrophoresis and gel diffusion of sputum in the diagnosis of pulmonary carcinomatosis: identification of the fast-moving component as albumin. Amer. Rev. resp. Dis., 85 351-363. 
Charman, J. (1974). Rheological properties of sputum: the influence of disease, infection and drugs. M. Phil., University of London. (In preparation).

Charman, J., Lopez-Vidriero, M. T., Keal, E. E., Mitchell-Heggs, P., and Reid, L. (1974). The properties of sputum in bronchorrhoea: a chemical and rheological study. (In preparation).

Das, 1. (1974). Enzymatic method for the estimation of mannose content in bronchial secretion. (In preparation).

Doumas, B. T., Watson, W. A., and Biggs, H. G. (1971). Albumin standards and the measurement of serum albumin with Bromcresol green. Clin. chim. Acta, 31, 87-96.

Gernez-Rieux, C., Voisin, C., Macquet, V., Clayes, C., Piat, G., and Fournier, P. (1961). Cancer alvéolaire avec bronchorrhée incoercible (étude clinique et biologique). Lille Méd., 6, 3-9.

Gernez-Rieux, C., Biserte, G., Havez, R., Voisin, C., Cuvelier, R., and Roussel, P. (1963). Intérêt de l'étude biochimique des prcteines de l'expectoration dans le cancer bronchiolo-alvéolaire. J. franc. Med. Chir. thor., 17, 799-811.

Gibbons, M. N. (1955). The determination of methylpentoses. Analyst, 80, 268-276.

Gibbons, R. A. (1959). Chemical properties of two mucoids from bovine cervical mucin. Biochem. J., 73, 209-217.

Gibbons, R. A., and Glover, F. A. (1959). The physicochemical properties of two mucoids from bovine cervical mucin. Biochem. J., 73, 217-225.

Gornall, A. G., Bardawill, C. J., and David, M. M. (1949). Determination of serum proteins by means of biuret reaction. J. biol. Chem., 177, 751-766.

Keal, E. E. F. (1971a). Biochemistry and rheology of sputum in asthma. Postgrad. med. J., 47, 171-177.

Keal, E. E. F. (1971b). The neuraminic acid content of sputum: its variation in disease and contribution to the physical properties. MD Thesis, University of London.

Keal, E. E. F., and Reid, L. (1972). Neuraminic acid content of sputum in chronic bronchitis. Thorax, 27, 643-653.

Kennamer, R. (1951). Pulmonary adenomatosis. J. Amer. med. Ass., $145,815-818$.

Lopez-Vidriero, M. T. (1974). Neuraminic acid, fucose and sulphate of sputum: in disease and during treatment. PhD Thesis, University of London. (In preparation).

Lopez-Vidriero, M. T., Charman, J., Keal, E. E. F., de Silva, D. J., and Reid, L. (1973). Sputum viscosity: correlation with chemical, and clinical features in chronic bronchitis. Thorax, 28 401-408.

Munies, R., Grubb, T. C., and Caliari, R. E. (1968). Relationship between sputum viscosity and total sialic acid content. J. pharm. Sci., 57, 824-827.

Odin, L. (1955). Sialic acid in pseudomyxomatous gels. Acta chem. scand., 9, 714-715.

Rubinstein, P., and Pilheu, J. A. (1954). Consideraciones sobre la broncorrea seromucosa. Rev. Assoc. méd. argent., 68, 471-473.

Ryley, H. C., and Brogan, T. D. (1973). Quantitative immunoelectrophoretic analysis of the plasma proteins in the sol phase of sputum from patients with chronic bronchitis. J. clin. Path., 26, 852-856.

Schools, G. S., and Ray, E. S. (1961). Bronchiolar carcinoma : a case report of bronchoscopic observation of severe bronchorrhoea. Dis. Chest, 39, 643-645.

Siltzbach, L. E. Personal communication.

Storey, C. F., Knudtson, K. P., and Lawrence, B. J. (1953). Bronchiolar 'alveolar cell' carcinoma of the lung. J. thorac. Surg., 26, 331406.

Sturgess, J. M. (1970). The control of the bronchial glands and their secretion. PhD Thesis, London University.

Turiaf, J., Marland, P., and Sors, C. (1957). Carcinose alvéolaire du poumon radiologiquement muette. J. franc. Méd. Chir. thor., 11, $115-128$.

Voisin, C. (1969). Hypersécrétion bronchique. Colloque Internationale de Pathologie Thoracique. (Lille 1968), pp. 23-43.

Warfringe, L. E. (1955). Paper electrophoresis of sputum in bronchiolar carcinoma (pulmonary adenomatosis). Acta med. scand. 153, 49-52.

Warren, L. (1959). The thiobarbituric acid assay of sialic acids. J. biol. Chem., 234, 1971-1975.

Wood, E. H., Jr. (1943). Unusual case of carcinoma of both lungs associated with lipid pneumonia Radiology, 40, 193-195. 